Autora na zarzuty o brak profesjonalizmu, czy wręcz o nienaukowy charakter publikacji. Należy jednak podkreślić, iż jest to świadomy zabieg, służący celom, które Autor postawil. W opinii P. W. Singera ,robotyzacja” wojny niesie ze sobą na tyle poważne konsekwencje dla całego społeczeństwa, iż zagadnienie to powinno zostać przybliżone możliwie najszerszemu gronu odbiorców. Stąd starania, aby język i styl książki były w maksymalnym stopniu przystępne dla czytelnika nieobeznanego z tematyką nauk wojskowych czy politycznych.

Recenzowana książka jest nietypową pozycją, łączącą w sobie treści naukowe i publicystyczne. Sam Autor przyznaje, iż celem tej publikacji, jest zarówno próba zrozumienia politycznych, wojskowych, społecznych i kulturowych konsekwencji postępującej ,robotyzacji" wojny, jak i zainicjowanie szerokiej debaty społecznej na ten temat. W opinii recenzenta cele te udało się osiągnąć. W kontekście opracowania naukowego wątpliwości może budzić swobodny styl publikacji oraz wyraźnie zarysowane tezy o charakterze publicystycznym. Jednak należy przyznać, iż służy to przejrzystości wywodu oraz przystępności książki dla szerokiego grona czytelników. Peter W. Singer zabrał w swej najnowszej publikacji głos w ważnej dyskusji na temat wpływu nowych technologii na charakter współczesnych konfliktów zbrojnych. Chociaż jego tezy są z pewnością dyskusyjne, to stanowią intrygujący punkt wyjścia dla dalszej debaty. Tym samym Wired for War [...] stanowi niezwykle ciekawą pozycję dla wszystkich zainteresowanych tematyką studiów strategicznych.

Rafał WIŚNIEWSKI

Uniwersytet im. Adama Mickiewicza, Poznań

\title{
Terroryzm. Materia ustawowa?, red. Krzysztof Indecki, Piotr Potejko, Agencja Bezpieczeństwa Wewnętrznego Centralny Ośrodek Szkole- nia im. Gen. Stefana Roweckiego "Grota" w Emowie, Warszawa 2009, ss. 186.
}

Wydany w 2009 roku przez Centralny Ośrodek Szkolenia Agencji Bezpieczeństwa Wewnętrznego zbiór trzynastu tekstów stanowi pozycję interesującą nie tylko ze względu na charakter wydawcy, znanego raczej z aktywności w dziedzinach innych niż edytorstwo naukowe. Różnorodność tematyki zamieszczonych prac wskazuje, iż redaktorzy opracowania przyjęli za cel możliwe pełną prezentację krajowych badań nad zjawiskiem terroryzmu. Zasadne jest też przypuszczenie, iż publikacja jest skierowana w pierwszym rzędzie do funkcjonariuszy ABW oraz innych służb i ma stanowić pomoc dydaktyczną w ośrodkach szkolenia.

Choć Autorzy zamieszczonych w omawianym zbiorze opracowań związani są z takimi podmiotami, jak: Agencja Bezpieczeństwa Wewnętrznego, Sąd Najwyższy, Ministerstwo Spraw Zagranicznych, Uniwersytet w Białymstoku, Uniwersytet Warszawski, Uniwersytet Lódzki, Uniwersytet im. Adama Mickiewicza w Poznaniu, Biuro Rzecznika Praw Obywatelskich, Dolnośląska Szkoła Wyższa we Wrocławiu, Wyższa Szkoła Przedsiębiorczości i Zarządzania im. L. Koźmińskiego, to - w ujęciu ilościowym - przeważają prace o charakterze prawoznawczym.

Książkę otwiera opracowanie Lecha K. Paprzyckiego pt. Czy Polsce potrzebna jest ustawa antyterrorystyczna? Autor opracowania w barwnym, eseistycznym zgoła stylu, 
opowiada o osobistym trzykrotnym ,otarciu się" o zjawisko terroryzmu na Sycylii, w RPA i w Izraelu. Z perspektywy sędziego z wieloletnią praktyką w Sądzie Najwyższym Autor przekonuje, że można pogodzić reguly demokratycznego państwa prawnego ze skutecznością państwa w przeciwdziałaniu i zwalczaniu przestępczości zorganizowanej, także terrorystycznej. Wskazuje przy tym na ewolucję instytucji świadka anonimowego oraz użyteczność instytucji świadka koronnego, a także istotne dla problematyki antyterrorystycznej rezultaty pracy nad nowelizacja ustawy o Policji oraz projektu ustawy o czynnościach operacyjno-rozpoznawczych. Autor uważa, że prace nad ustawą antyterrorystyczną należy rozpocząć od poznania wszelkich unormowań prawnych różnej rangi „od Konstytucji poczynając, a na najbardziej szczegółowej i najbardziej tajnej instrukcji kończąc”. Nie można jednak bezkrytycznie zgodzić się z tezami Autora, że, ,istnienie takiej ustawy w Polsce jest niezbędne" oraz ,że zagrożenie terroryzmem w Polsce jest w porównaniu z wieloma państwami Europy znacząco wyższe", zwłaszcza, że w ogóle nie starał się zaprezentować argumentacji na rzecz tych twierdzeń. Stwierdzenie Lecha K. Paprzyckiego przedstawione już na wstępie, że należy „do grona tych, którzy na temat problematyki terroryzmu wiedzą wyjatkowo mało" oraz dalsze wywody Autora dotyczace wlasnych kompetencji moga wywołać powstanie pewnych wątpliwości u osób czytających ten wartościowy skądinąd artykut.

Paweł Chomentowski i Piotr Tchorzewski w opracowaniu pt.: Ustawa antyterrorystyczna. Próba analizy podjęli wysiłek przybliżenia zagadnien, na których kanwie powinny zostać oparte podstawowe założenia ustawy antyterrorystycznej. Autorzy przekonuja, że odrębny akt rangi ustawowej powinien zawierać wykaz kategorii potencjalnych zdarzeń związanych z zagrożeniami terrorystycznymi, co mogłoby okazać się pomocne w określeniu zakresu współpracy i kompetencji poszczególnych służb i instytucji. Kwestią dyskusyjną pozostaje, czy na pewno instytucją wiodąca, z ustawowo nadanymi uprawnieniami koordynatora wymiany informacji, powinno nadal być Centrum Antyterrorystyczne dzialające w ramach struktur $\mathrm{ABW}$. Nie sposób natomiast nie zgodzić się z Autorami, że stworzenie czytelnej i kompleksowej regulacji wymagać będzie doprecyzowania istniejących przepisów prawa nie tylko karnego, lecz także imigracyjnego, bankowego, lotniczego oraz wypracowania procedur, w tym również dotyczących relacji międzypaństwowych.

Robert Drzazga w opracowaniu pt. Konwencje antyterrorystyczne ONZ - charakterystyka oraz zakres zobowiazań nalożonych na państwa - strony w bardzo przystępny sposób przedstawia międzynarodowe rozwiązania w zakresie zwalczania terroryzmu. Omawiając 13 sektorowych Konwencji antyterrorystycznych przyjętych przez Organizację Narodów Zjednoczonych, Autor zawraca uwagę na koherentność polskiego ustawodawstwa z prawem międzynarodowym. Ponadto wskazuje na konieczność naprawy występujących w polskim prawie niedociagnięć $w$ zakresie przeciwdziałania finansowaniu terroryzmu. Po lekturze artykuhu R. Drzazgi nasuwa się przekonanie, że ustawowe unormowanie problematyki terrorystycznej jest zadaniem niezwykle trudnym. Autor dowodzi, iż pomimo wieloletnich starań do porządku prawnomiędzynarodowego nie udało się dotąd wprowadzić uniwersalnej konwencji całościowo wyczerpującej omawianą tematykę. Na tym forum nie osiagnięto także kompromisu koniecznego do zdefiniowania zjawiska terroryzmu międzynarodowego.

W opracowaniu pt. Formy zwalczania terroryzmu na podstawie wybranych uregulowan Unii Europejskiej i NATO Wojciech Filipkowski w ramach czterech rozdziałów przybliżył rys historyczny, począwszy od pojawienia się zjawiska terroryzmu na forum Wspólnot 
Europejskich w połowie lat siedemdziesiątych, wybrane akty prawne, unijną strategię walki z terroryzmem oraz strategię NATO. Autor już na wstępnie opracowania zauważa, że w zjawisku terroryzmu - choć znanym od dawna - zachodzą obecnie zmiany jakościowe. Wprowadza znany z literatury przedmiotu termin „nowy terroryzm”. Autor nie pokusił się jednak o wymienienie cech odróżniających ,nowy terroryzm” od tradycyjnych postaci tego zjawiska, co znacznie ułatwiłoby zrozumienie jego dalszych rozważań, zwłaszcza czytelnikom mniej zorientowanym w omawianej problematyce. Na uwagę natomiast zasługuje fakt, że Autor opisując opór wobec wprowadzenia przygotowanych rozwiązań legislacyjnych, wynikający z braku woli politycznej i poparcia społecznego, dostrzega, iz: ,niektórzy zarzucają władzom także i to, że w makiaweliczny sposób sterują strachem, podsycają go, w celu poszerzenia uprawnień dla organów ścigania i służb specjalnych”, co w konsekwencji powoduje „ograniczenie praw i wolności obywatelskich, w szczególności prawa do prywatności." Zdaniem Autora, przygotowując jakikolwiek fragment regulacji antyterrorystycznej, należy mieć to na uwadze.

Zdzisław Galicki, Autor opracowania pt. Zapobieganie terroryzmowi w świetle prawa międzynarodowego: konfrontacja z prawem europejskim i krajowym przedstawia ewolucję podejścia do zjawiska terroryzmu międzynarodowego. Pierwotne podejście koncentrowało się ,na kryminalizacji różnych postaci terroryzmu oraz ich zwalczaniu i skutecznym karaniu sprawców". System nieuchronnych i surowych kar mial działać odstraszająco dla przyszlych potencjalnych terrorystów. Dopiero w 2005 roku, po wielu burzliwych staraniach, przyjęta została Konwencja Rady Europy o zwalczaniu terroryzmu, którą wyróżniało działanie prewencyjne ,poprzez kryminalizacje przestępstw poprzedzajacych i przygotowujących ewentualne dokonanie ataków terrorystycznych". Autor podkreśla również istnienie rozbieżności występujących między konwencja z 2005 roku a decyzją ramowa z 2008 roku, co nastręcza trudności w wyborze aktu, z którego mają zostać zaczerpnięte rozwiązania przy tworzeniu krajowej ustawy antyterrorystycznej.

Opracowanie autorstwa Ewy M. Guzik-Makaruk pt. Rozwiazania materialnoprawne w obszarze penalizacji terroryzmu w Republice Federalnej Niemiec $i$ Austrii na tle decyzji ramowej Rady Unii Europejskiej w sprawie zwalczania terroryzmu niewatpliwie będzie stanowić cenny materiał dla osób zainteresowanych komparatystyczną refleksją nad prawem antyterrorystycznym, której to znaczenie trudno przecenić na dowolnym etapie procesu tworzenia prawa. Autorka podkreśla, że Niemcy były prekursorami kryminalizacji motywowanych politycznie czynów o charakterze antypaństwowym wprowadzając już w 1871 roku odpowiednie przepisy do obowiązującego do dziś (ze zmianami) Kodeksu karnego. Autorka stwierdza: „Trzeba pamiętać, że § 129 StGB [Kodeksu karnego - przyp. aut.] był nagminnie wykorzystywany w czasach narodowego socjalizmu do zwalczania wrogów politycznych". Nota bene sam patron emowskiego ośrodka ABW został uwięziony w KL Dachau na podstawie niemieckich przepisów (antyterrorystycznych?) obowiązujących w pierwszej połowie lat czterdziestych XX wieku.

Krzysztof Indecki w tekście pod tytułem Stosowanie praw czlowieka wobec sprawców aktów terrorystycznych zauważa, że podejmowane przez niektóre państwa działania, mające przeciwdziałać i zapobiegać aktom terrorystycznym, realizowane są za pośrednictwem odrębnych regulacji prawa karnego, przewidzianych specjalnie dla sprawców aktów terrorystycznych. „Odrębne zasady postępowania np. w postaci legalizacji wobec nich tortur lub innego niehumanitarnego lub nieludzkiego traktowania" nie tylko dają efekty odwrotne od zamierzonych, ale także prowadzą do ,obniżenia standardów stosowania prawa, dobrego 
rządzenia i praw człowieka". Autor uważa, że terroryzm nie może być usprawiedliwieniem dla braku respektowania praw człowieka. Państwo ma obowiązek przeciwdziałać i reagować na akty terrorystyczne, ale musi wywiązywać się z podyktowanego porządkiem prawnomiędzynarodowym obowiązku respektowania i chronienia praw człowieka we własnym prawie karnym, cywilnym i administracyjnym. Autor przytacza wypowiedź Sekretarza generalnego ONZ Kofi Annana, który stwierdził: ,ochrona praw człowieka wszystkich ludzi - tych podejrzanych o terroryzm, jego ofiar i osób dotkniętych konsekwencjami terroryzmu - jest konieczna dla skuteczności strategii zwalczania terroryzmu".

Arkadiusz Kalicki, Autor artykułu pt. Aspekty prawne w brytyjskim systemie zwalczania terroryzmu, dokonal szczegółowej analizy obwiązującego w Wielkiej Brytanii ustawodawstwa związanego z działalnością terrorystyczną na tle narastającego zagrożenia zarówno w tym państwie, jak i na świecie. Autor zaznajamia czytelnika z problemami, z którymi do tej pory boryka się brytyjskie prawodawstwo. Autor porusza problem ustalenia i przyjęcia przez władze brytyjskie definicji określającej zjawisko terroryzmu. Zwraca uwagę na rozszerzającą się, a niepokojącą ingerencję państwa w prawa obywateli, przy jednoczesnym wzmacnianiu środków represji pozostających w gestii państwa. Jako przykład podaje kwestię systematycznego zwiększania okresu zatrzymania bez postawienia zarzutów - brytyjskie sfery policyjne domagaja się prawa do aresztowania w tym trybie podejrzanych o terroryzm na 90 dni. Zdaniem A. Kalickiego utrzymanie odpowiednich proporcji pomiędzy uprawnieniami administracji a wolnością jednostki, w związku z walką z terroryzmem, będzie w najbliższych latach najpoważniejszym wyzwaniem stojącym przed państwem brytyjskim.

W artykule pt. Regulacje antyterrorystyczne z punktu widzenia praw i wolności człowieka i obywatela Autorzy Adam Krzywoń i Mirosław Wróblewski wskazują na internacjonalizację zjawiska terroryzmu, którego eskalacja przyczyniła się do ustanowienia licznych aktów prawa międzynarodowego oraz wprowadzenia często kontrowersyjnych wewnątrzpaństwowych antyterrorystycznych rozwiązań legislacyjnych, jak np. w Stanach Zjednoczonych oraz największych państwach Europy Zachodniej. Po przeprowadzeniu szczegółowej analizy popartej przykładami, Autorzy dochodzą do konkluzji, że odnalezienie ,złotego środka" jest niezwykle trudne i zawsze dotyka konstytucyjnych fundamentów państwa. Jeżeli dopuści się do realnego zagrożenia bezpieczeństwa, konstytucyjne gwarancje wolności stracą na znaczeniu. $Z$ drugiej strony sami możemy z tych wartości zrezygnować, starając się zapewnić bezpieczeństwo poprzez wprowadzenie nieproporcjonalnych ograniczeń wolności i praw obywatelskich.

Katarzyna Laskowska w opracowaniu pt. Aktualny stan antyterrorystycznego ustawodawstwa w Federacji Rosyjskiej. Próba analizy i oceny skoncentrowała się na przedstawieniu aktualnego zakresu ustawodawstwa antyterrorystycznego obowiazującego w Rosji na podstawie uchwalonej w 2006 roku ustawy o przeciwdziałaniu terroryzmowi. Przedstawia pogląd, że ,jest to właściwe rozwiązanie prawne, zasługujące na naśladowanie w warunkach polskich". Autorka szczegółowo omówiwszy rozwiązania rosyjskiej ustawy z 6 marca 2006 r. „O protiwodiejstwii tierrorizmu” dostrzega takie jej zalety jak kompleksowość, ukierunkowanie na przeciwdzialanie zjawisku, a nawet to, że ,przewiduje ulgi emerytalne dla funkcjonariuszy biorących udział w akcjach antyterrorystycznych". Pokusiła się przy tym o rzeczową krytykę tego aktu prawnego. W tym miejscu wylicza takie jego wady, jak: określenie terroryzmu jako ideologii, szerokie ujęcie działalności antyterrorystycznej oraz brak gwarancji praworządności w ramach operacji antyterrorystycznych. Według Autorki 
ustawa nie przewiduje prawnych mechanizmów kontroli nad działaniami antyterrorystycznymi, takich jak nadzór prokuratorski czy sądowy. Zarzuca rosyjskiej ustawie również to, że nakłada na siły zbrojne zadania stricte policyjne. Nieco zagadkowe pozostają zatem powody, dla których Autorka uznaje omawiane przez nią rozwiązania rosyjskie za wzór do naśladowania w naszym kraju.

Piotr Mickiewicz, Autor artykuhu pt. Przeciwdziatanie zagrożeniu terrorystycznemu $i$ konsekwencji ataku terrorystycznego na polskich akwenach morskich. Analiza prawna i postulowany model organizacyjny zmierzył się z tematyka, która w literaturze nie zajmuje zbyt eksponowanego miejsca, a która zasługuje na uwagę. Jest to, najkrócej mówiąc, kwestia zarządzania kryzysowego na wodach wewnętrznych i morzu terytorialnym, ujęta z perspektywy lekko antyterrorystycznej.

Cezariusz Sońta w opracowaniu pt. Przestępstwo o charakterze terrorystycznym w prawie polskim dokonuje szczegółowej analizy obowiązujących w naszym kraju przepisów prawa. Nie wdając się w ocenę tej analizy, odnotuję tu jedynie fakt, iż Autor przytacza za przedstawicielami Ośrodka Informacji ONZ w Warszawie syntetyczna, a zarazem adekwatną definicję, która za terroryzm uznaje „,różnie umotywowane ideologicznie planowane i zorganizowane działania pojedynczych osób lub grup skutkujące naruszeniem istniejącego porządku prawnego, podjęte w celu wymuszenia od wladz państwowych i spoleczeństwa określonych zachowań i świadczeń, często naruszające dobra osób postronnych. Dzialania te realizowane są z calą bezwzględnością za pomocą różnych środków (przemoc fizyczna, użycie broni i ładunków wybuchowych), w celu nadania im rozgłosu i celowego wytworzenia 1ęku w społeczeństwie" (s. 156).

Książkę zamyka artykuł Sebastiana Wojciechowskiego pt. Opinie Polaków na temat terroryzmu - analiza wybranych aspektów, w którym Autor przypomina o innych ważkich obszarach badań nad zjawiskiem terroryzmu, często zaniedbywanych w krajowej literaturze przedmiotu. Autor analizuje - także w aspekcie zmian - wyniki badań sondażowych dotyczących postrzegania zjawiska terroryzmu oraz poczucia bezpieczeństwa w polskim społeczeństwie. W omawianym zbiorze przeważają prace z dziedziny prawa, dotyczące różnych form zwalczania terroryzmu. Refleksja - zwlaszcza prawnicza - nad zjawiskiem terroryzmu nie może pominąć jego aspektu socjologicznego. Z tego punktu widzenia artykuł jest niezmiernie istotny dla realizacji celu, który sam Autor określa następującymi słowami: „stworzyć w pełni polski - kompleksowy system antyterrorystyczny, wykorzystujący doświadczenia innych państw, ale uwzględniający przede wszystkim polskie realia oraz dynamikę i ewolucję zjawiska".

Omawiana książka jest wartościową pozycja, która ze względu na problematykę może zainteresować czytelników należących do środowiska funkcjonariuszy służb odpowiedzialnych za bezpieczeństwo państwa oraz pracowników administracji państwowej. Osoby zajmujące się legislacją, a także naukowo tematyką terroryzmu powinny się z nią zapoznać - na pewno nie poczują się zawiedzione. Należy jednak podkreślić, że mamy do czynienia z książką przeznaczoną dla czytelników, którym nieobce są podstawy prawoznawstwa. 